\title{
Correction to: Detection of Candidatus Neoehrlichia mikurensis in Norway up to the northern limit of Ixodes ricinus distribution using a novel real time PCR test targeting the groEL gene
}

Andrew Jenkins ${ }^{1 *}$, Cecilie Raasok ${ }^{1,2}$, Benedikte N. Pedersen ${ }^{1}$, Kristine Jensen ${ }^{1,3}$, Åshild Andreassen ${ }^{1,4}$, Arnulf Soleng ${ }^{5}$, Kristin Skarsfjord Edgar ${ }^{5}$, Heidi Heggen Lindstedt ${ }^{5}$, Vivian Kjelland ${ }^{6,7}$, Snorre Stuen ${ }^{8}$, Dag Hvidsten ${ }^{9}$ and Bjørn-Erik Kristiansen ${ }^{10}$

\section{Correction to: BMC Microbiol}

https://doi.org/10.1186/s12866-019-1502-y

After publication of our article [1] it came to our notice that the source of the sequence for the control plasmid, pNeo (Materials and methods: Controls) was incorrectly stated as AB094461. The correct accession number is AB074461. The authors apologize for any confusion this may have caused.

\section{Author details \\ 'Department of Natural Science and Environmental Health, University of South-Eastern Norway, Bø, Norway. ${ }^{2}$ Present address: Nittedal Municipal Water and Drainage Authority, Nittedal, Norway. ${ }^{3}$ Present address: Telemark Trust Hospital, Section for Pathology, Skien, Norway. ${ }^{4}$ Department of Virology, Norwegian Institute of Public Health, Oslo, Norway. ${ }^{5}$ Department of Pest Control, Norwegian Institute of Public Health, Oslo, Norway. ${ }^{6}$ Department of Engineering and Science, University of Agder, Kristiansand, Norway. ${ }^{7}$ Sørlandet Trust Hospital Research Unit, Kristiansand, Norway. ${ }^{8}$ Department of Production Animal Clinical Sciences, Norwegian University of Life Sciences, Sandnes, Norway. ${ }^{9}$ Department of Microbiology and Infection Control, University Hospital of North Norway, Tromsø, Norway. ${ }^{10}$ Department of Process, Energy, and Environmental Technology, University of South-Eastern Norway, Porsgrunn, Norway.}

Published online: 10 January 2020

\section{Reference}

1. Jenkins, et al. Detection of Candidatus Neoehrlichia mikurensis in Norway up to the northern limit of Ixodes ricinus distribution using a novel real time PCR test targeting the groEL gene. BMC Microbiol. 2019;19:199. https:// doi.org/10.1186/s12866-019-1502-y.

The original article can be found online at https://doi.org/10.1186/s12866019-1502-y

*Correspondence: andrew.jenkins@usn.no

'Department of Natural Science and Environmental Health, University of

South-Eastern Norway, Bø, Norway

Full list of author information is available at the end of the article

(c) The Author(s). 2020 Open Access This article is distributed under the terms of the Creative Commons Attribution 4.0 International License (http://creativecommons.org/licenses/by/4.0/), which permits unrestricted use, distribution, and reproduction in any medium, provided you give appropriate credit to the original author(s) and the source, provide a link to the Creative Commons license, and indicate if changes were made. The Creative Commons Public Domain Dedication waiver (http://creativecommons.org/publicdomain/zero/1.0/) applies to the data made available in this article, unless otherwise stated. 